\title{
Use of complementary and alternative medicine among paediatric patients with hepatogastrointestinal diseases
}

Seyed Hamdollah Mosavat, ${ }^{1,2}$ Mojtaba Heydari, ${ }^{1}$ Mohammad Hashem Hashempur ${ }^{3}$ and Seyed Mohsen Dehghani ${ }^{4}$

${ }^{1}$ Pharmaceutical Sciences Research Center, ${ }^{2}$ Research Center for Psychiatry and Behaviour Science, ${ }^{4}$ Department of Paediatric Gastroenterology, Namazi Hospital, Shiraz University of Medical Sciences, Shiraz, Islamic Republic of Iran (Correspondence to: Seyed M. Dehghani: dehghanism@sums.ac.ir; Mohammad Hashem Hashempur: hashempur@gmail.com). ${ }^{3}$ Noncommunicable Diseases Research Center, Fasa University of Medical Sciences, Fasa, Islamic Republic of Iran.

\begin{abstract}
Background: The use of complementary and alternative medicine (CAM) is becoming increasingly popular in Middle Eastern countries; it is often used for paediatric medical conditions such as chronic gastrointestinal complaints and failure to thrive. It is also commonly used in patients with chronic hepatic conditions such as cirrhosis and in hepatic transplant patients.

Aims: This study aimed to evaluate the prevalence, types and associated factors of CAM use in children with hepatogastrointestinal disease in Shiraz, Islamic Republic of Iran.

Methods: In a cross-sectional study carried out during September 2013-January 2014, 238 parents of children attending a paediatric gastroenterology and hepatology clinic at Shiraz University of Medical Sciences received a self-administered questionnaire covering associated factors of complementary and alternative medicine use; 210 questionnaires were completed and returned.

Results: Complementary and alternative medicine was used by 103 patients (49\%); 74 (71.8\%) of these used herbal remedies. Older age of the child significantly increased CAM use. Those with previous positive experience of CAM (62.1\% of users, $40.2 \%$ of non-users) and those who had received recommendation for CAM by health care providers ( $24.3 \%$ of users, $6.6 \%$ of non-users) were significantly more likely to use CAM.
\end{abstract}

Conclusions: This survey demonstrated the high prevalence of CAM use (especially herbal remedies) in paediatric patients with hepatogastrointestinal diseases.

Keywords: hepatogastrointestinal disease; children; Iran; complementary and alternative medicine (CAM)

Citation: Mosavat SH; Heydari M; Hashempur MH; Dehghani SM. Use of complementary and alternative medicine among paediatric patients with hepatogastrointestinal diseases. East Mediterr Health J. 2018;24(10):1018-1025. https://doi.org/10.26719/2018.24.10.1018

Received: 04/07/15; accepted: 23/07/17

Copyright (C) World Health Organization (WHO) 2018. Some rights reserved. This work is available under the CC BY-NC-SA 3.o IGO license (https:// creativecommons.org/licenses/by-nc-sa/3.o/igo).

\section{Introduction}

Complementary and alternative medicine (CAM) covers a broad range of therapies that are outside conventional medicine (1). It is defined as "a group of diverse medical and health care systems, practices, and products that are not presently considered to be a part of conventional medicine "according to National Center for Complementary and Alternative Medicine in the United States of America (2). Recently, there has been a tendency toward using CAM (3). Several studies have evaluated the prevalence of CAM use and its associated factors in recent decades. Many have shown the noticeably prevalent use of CAM associated with factors such as age, race, socioeconomic status, education level, severity of disease and availability $(4,5)$.

Several specific considerations are discussed on CAM use in paediatric patients. Ethical considerations due to inability of informed selection of therapeutic modality along with the narrow gap between therapeutic and toxic doses in paediatric patients make CAM use more challenging in this group.

The prevalence of CAM use in children has been reported as a wide range, from $10 \%$ to more than $80 \%$ of the study population (5-8), mainly due to different CAM definitions and study populations or different sample size (9). As an instance, among children with cancer, juvenile rheumatoid arthritis and cystic fibrosis, utilization of CAM is more prevalent (10). Some studies examined the use of CAM, comparing groups of children presenting with different diseases which leads to different results (5).

Among paediatric medical conditions, chronic gastrointestinal complaints and diseases such as chronic constipation, chronic abdominal pain and failure to thrive, along with patients with chronic hepatic diseases such as cirrhosis and hepatic transplant patients, are also disposed to high prevalence of CAM use (11). Use of CAM in these patients has specific considerations such as potential lower toxic doses and different herb and drug interactions in the absence of normal liver metabolism. These facts emphasize the need for more information on CAM use and associated factors in children with hepatic and gastrointestinal diseases.

This study aimed to evaluate the prevalence and type of CAM use in patients attending a paediatric 
hepatogastrointestinal clinic at Shiraz University of Medical Sciences. In addition, we attempt to describe child- and parent-related factors associated with the use of CAM.

\section{Methods}

\section{Study design and sampling}

We conducted a cross-sectional study on a convenience sample of 238 parents of paediatric patients presenting for health care visits at Shiraz University of Medical Sciences paediatric gastroenterology and hepatic referral clinic from September 2013 to January 2014. The study population was limited to parents of children with any gastrointestinal disease that were referred to the paediatric gastroenterology and hepatic clinic.

The study protocol was approved by the Medical Ethics Committee of Shiraz University of Medical Sciences (approval number: 90-5765).

\section{Data collection}

The researchers developed and piloted a survey on 20 parents (separate from the study group) to determine the information necessary to address the aims of the study.

Parents who were referred for their child to be visited by the paediatric gastroenterologist were invited to participate in this study. After signing the informed consent form, they filled out a self-administered questionnaire which took about 15-20 minutes to complete. Parents who for any reason were not able to express their ideas or filled out the questionnaires incompletely were excluded from the study. We designed the semi-structured questionnaire based on the current literature and our study goals. The questionnaire consisted of 16 questions including both open- and closed-ended questions, which were categorized into 2 domains. The first domain consisted of 9 questions regarding sociodemographic data such as child's and parents' age, parents' education status, type of child's disease and residence. The second domain consisted of 7 questions about the use of CAM within the last year, the type of CAM used, positive previous experiences about the beneficial effects of CAM, local access to CAM, the patient's view about possible interactions of CAM with chemical drugs.

It was necessary for us to mention popular types of CAM that are practised among Iranian people to better define CAM for participants. Also, the patients' parents determined the type of disease for which CAM is used (e.g. abdominal pain, constipation, jaundice, diarrhoea, reflux and inflammatory bowel disease), type of CAM used, previous recommendations or prohibition by their health care providers, previous positive or negative experience with CAM and their access to CAM providers

\section{Statistical analysis}

Descriptive statistics were used to characterize the study participants overall and within subgroups. Bivariate comparisons of the user and non-user groups were made using the Chi-squared test for categorical variables and the $t$-test for continuous variables. $P$ values $<0.05$ were considered statistically significant.

Multiple logistic regression analysis was undertaken to determine the independent association between CAM use and the multivariate predictors. Selected variables in the logistic regression model were based on the analysis of each variable using Chi-squared and the independent $t$-test. If the $P$ value was $\leq 0.25$, the variable was then examined using logistic regression.

\section{Results}

From 238 questionnaires distributed, a total of 210 $(88.23 \%)$ were completed. Twenty eight patients $(11.76 \%)$ were excluded from the study because they refused to complete the questionnaires or filled out the questionnaires incompletely.

The mean age of the paediatric patients was 6.2 [standard deviation (SD) 4.9] years (range 1 month-19 years) and the mean age of the mothers and fathers was 31.6 (SD 6.35) years (range 23-68 years) and 36.3 (SD 7.58) years (range 18-51 years) respectively. Patients presented with a variety of diseases, including gastrointestinal diseases $(46.6 \%)$, hepatic diseases $(31.1 \%)$ and failure to thrive $(6.8 \%)$ (Table 1$)$.

Details of sociodemographic characteristics of the participants and associated factors in CAM users versus non-users are shown in Table 1.The use of CAM was not influenced by the parents' attitude about side-effects $(P=0.063)$ nor their attitude about the results of the combination of CAM with routine drugs $(P=0.195)$.

One hundred and three patients (49\%) used CAM in the course of their hepatogastrointestinal disease; 74 (71.8\%) used herbal remedies and 46 (44.6\%) used other types of CAM (Table 2). Spiritual therapy was sued by $35.9 \%$. It should be noted that the patients were allowed to choose more than one option, so the summation of values may total more than $100 \%$. Among the herbal remedies, the most common ones used in hepatogastrointestinal diseases by the study population are shown in Table 3 . Descurainia sophia $(33 \%)$ and Thymus vulgaris $(16 \%)$ were the 2 most commonly mentioned.

No significant difference in the rate of CAM use was observed among patients with different parents' ages $(P$ $=0.35$ and $P=0.09$ for mothers and fathers respectively) (Table 2), but logistic regression analysis showed that older age of the child significantly increased CAM use (OR $0.08 ; P=0.036$ ) (Table 4).

Patients with previous positive experience of CAM (62.1\% of users vs $40.2 \%$ of non-users, $P=0.046)$ and patients who had received recommendation for CAM use by health care providers $(24.3 \%$ of users vs $6.6 \%$ of non-users, $P=0.001$ ) were significantly more likely to use CAM than others according to logistic regression analysis (Tables1,4). But prohibition of CAM use by health care providers did not significantly affect the prevalence of CAM use $(20.4 \%$ of users vs $20.6 \%$ of non-users, $P=$ 0.97). 


\begin{tabular}{|c|c|c|c|c|}
\hline \multirow[t]{3}{*}{ Characteristic } & \multirow{3}{*}{$\begin{array}{c}\text { CAM } \\
\text { users } \\
\text { Mean (SD) }\end{array}$} & \multirow{3}{*}{$\begin{array}{c}\text { CAM } \\
\text { non-users } \\
\text { Mean (SD) }\end{array}$} & \multicolumn{2}{|c|}{ P-value } \\
\hline & & & $\begin{array}{l}\text { Bivariate } \\
\text { analysis }\end{array}$ & $\begin{array}{l}\text { Logistic } \\
\text { regression }\end{array}$ \\
\hline & & & & \\
\hline \multicolumn{5}{|l|}{ Age (years) } \\
\hline Mother & $31.26(5.67)$ & $32.08(6.96)$ & 0.35 & 0.037 \\
\hline Father & $35.46(6.27)$ & $37.21(8.61)$ & 0.09 & \\
\hline Child & $5.63(4.39)$ & $6.83(5.44)$ & 0.08 & \\
\hline \multirow{2}{*}{ No. of children in family } & $1.9(1.0)$ & $2.0(1.0)$ & 0.39 & \\
\hline & $\%$ & $\%$ & & \\
\hline \multicolumn{5}{|l|}{ Residence } \\
\hline Urban & 47.6 & 47.7 & 0.98 & \\
\hline Rural & 52.4 & 52.3 & & \\
\hline \multicolumn{5}{|l|}{ Availability of CAM } \\
\hline Available & 70.9 & 58.0 & 0.051 & 0.090 \\
\hline Unavailable & 29.1 & 42.0 & & \\
\hline \multicolumn{5}{|c|}{ Previous positive experience with CAM } \\
\hline Yes & 62.1 & 40.2 & 0.001 & 0.040 \\
\hline No & 37.9 & 58.8 & & \\
\hline \multicolumn{5}{|c|}{ Parents' attitude about side-effects of CAM } \\
\hline Mild & 57.3 & $54 \cdot 3$ & 0.063 & \\
\hline Moderate & 29.1 & 38.3 & & \\
\hline Severe & 13.6 & 7.4 & & \\
\hline \multicolumn{5}{|c|}{$\begin{array}{l}\text { Parents' attitude about CAM combination with children's } \\
\text { conventional drugs }\end{array}$} \\
\hline Synergic effects with drugs & 37.8 & 23.4 & 0.195 & \\
\hline Interaction with drugs & 43,7 & 50.5 & & \\
\hline None & 18.5 & 26.1 & & \\
\hline \multicolumn{5}{|c|}{ Health care provider recommended CAM } \\
\hline Yes & $24.3 \%$ & 6.6 & $<0.0001$ & 0.001 \\
\hline No & $75.7 \%$ & 93.4 & & \\
\hline \multicolumn{5}{|c|}{ Health care provider prohibited CAM } \\
\hline Yes & 20.4 & 20.6 & 0.97 & \\
\hline No & 79.6 & 79.4 & & \\
\hline \multicolumn{5}{|l|}{ Disease type } \\
\hline Hepatic & 31.1 & 28.0 & 0.29 & \\
\hline Gastrointestinal & 46.6 & 33.6 & & \\
\hline Failure to thrive & 6.8 & 7.5 & & \\
\hline Other & 15.5 & 30.9 & & \\
\hline
\end{tabular}

$S D=$ standard deviation .

\section{Discussion}

Our findings demonstrated the prevalence and associated factors of CAM use in paediatric patients referred to Shiraz University of Medical Sciences paediatric hepatogastroenterology clinic. This study showed that $49 \%$ of the patients used at least 1 type of CAM. Herbal remedies were the most common type used. Older child age was associated with the use of CAM. Additionally, the patients who were advised by their health care provider to use CAM and those who had previous positive experience with CAM were more likely to use it.

Complementary and alternative medicine is commonly used in the Iranian population, especially herbal medicine $(12,13)$. Several studies have been done on the pattern and associated factors of CAM use in different diseases, and prevalence ranged from $10 \%$ to $67 \%$. This wide range was influenced by differences in the population samples and types of CAM (14-18).

To the best of our knowledge, although there has been no study that evaluated the prevalence and type of CAM used in paediatric patients with hepatogastrointestinal diseases in Iran, the prevalence rate of CAM use in our study was similar to the findings of Tonekaboni et al. for epileptic children in Tehran (17). They reported a 44\% prevalence of CAM use. Additionally, our result on the use of CAM is similar to those of 2 studies conducted in Turkey and Switzerland. Arýkan et al. in their survey on 


\begin{tabular}{|c|c|}
\hline \multicolumn{2}{|c|}{$\begin{array}{l}\text { Table } 2 \text { Distribution of types of complementary and } \\
\text { alternative medicine (CAM) used by paediatric patients } \\
(n=103) \text { with hepatogastrointestinal diseases, Shiraz, } \\
2013-2014\end{array}$} \\
\hline Type of CAM & Users (\%) ${ }^{a}$ \\
\hline \multicolumn{2}{|l|}{ Natural products } \\
\hline Herbal remedies & 71.8 \\
\hline Swallowing raw fish & 5.8 \\
\hline Other & 5.2 \\
\hline \multicolumn{2}{|l|}{ Mind and body practices } \\
\hline Spiritual therapy & 35.9 \\
\hline Energy healing therapy & 3.8 \\
\hline Wet cupping & 2.9 \\
\hline Gem therapy & 1.9 \\
\hline Other & 2.9 \\
\hline
\end{tabular}

aPatients may use more than one type of CAM.

\begin{tabular}{lc}
\hline Table 3 Herbs commonly used for paediatric patients \\
( $\mathbf{n = 1 0 3 )}$ with hepatogastrointestinal diseases, Shiraz, \\
$\mathbf{2 0 1 3 - 2 0 1 4}$ & $\%$ \\
\hline Herb species & 33 \\
Descurainia sophia & 16 \\
Thymus vulgaris & 13 \\
Cotoneaster sp. & 11 \\
Alhagi maurorum & 5 \\
Fumaria officinalis & 4 \\
Mentha piperita & 4 \\
Ziziphus jujuba & 4 \\
Borago officinalis & 4 \\
Olea europaea & 18 \\
Other & 4 \\
\hline
\end{tabular}

children with type I diabetes demonstrated CAM use by $52 \%$ of them (19). Moreover, Zuzak et al. reported 58\% CAM use in a population of paediatric patients presenting to an emergency department (20).

However, our results are in contrast with those of several other studies on paediatric patients. For example, $19 \%$ of parents of children with type I diabetes at an American urban paediatric clinic reported CAM use for their children (21). Another study in a primary paediatric care centre in Washington DC reported CAM use in $21 \%$ of children (22). Also, a survey in a general paediatric clinic reported a lower CAM use (30\%), in contrast to our findings (23).

As in previous Iranian research on prevalence of CAM use (24), herbal remedies were the most common form, $(71.8 \%)$ of CAM use in our study. However, some investigations on CAM use for paediatric patients reported herbal medicine use by $40-60 \%$ of CAM users (19,21-23). Spiritual therapy was another common type of CAM reported in our study. This is probably due to the religious beliefs which are very common in Iranian culture.

Live raw fish swallowing was a traditional remedy in Iranian folklore medicine for treatment of paediatric jaundice (25). This folk habit was also reported to be used in other countries (26) and is associated with the risk of parasitic infections (27).

Among the herbal remedies used, Descurainia sophia is one of the most common herbs used in Traditional Persian Medicine as a neonatal jaundice remedy (28-30). Although we did not find any study about the relationship between D. sophia and jaundice, some research that showed anti-inflammatory and laxative effects of D. sophia (31,32). Thymus vulgaris is another plant used frequently by patients, especially for abdominal pain. The antispasmodic and gastrotonic effects of this plant are supported by previous studies (33,34). Taranjabin, or Persian manna, and Cotoneaster are traditional laxatives used commonly in paediatric patients (35), and are traditionally used in the management of neonatal jaundice. Some clinical studies support the efficacy of these herbs in the treatment of neonatal jaundice (3638). However, according to the most famous resources of Traditional Persian Medicine, such as the Canon of medicine by Avicenna (980-1037 AD) (39), and the Liber continens of Rhazes (865-925 AD) (40), there is no scientific support for some of these uses.

The reasons for the use of medicinal herbs by the Iranian population are clear. Briefly, several investigations indicate their relative efficacy in some traditional uses. Also, Traditional Persian Medicine has a long history and there are inextricable relationships with the daily life of

\begin{tabular}{|c|c|c|c|}
\hline \multirow[t]{2}{*}{ Variable } & \multirow{2}{*}{$\begin{array}{l}\text { Odds } \\
\text { ratio }\end{array}$} & \multicolumn{2}{|c|}{$95 \%$ confidence interval } \\
\hline & & Lower bound & Upper bound \\
\hline (Constant) & 0.354 & -0.075 & 0.782 \\
\hline Availability of CAM & 0.117 & -0.024 & 0.257 \\
\hline Previous positive experience with CAM & 0.139 & 0.002 & 0.275 \\
\hline Parents' attitude about CAM combination & 0.067 & -0.024 & 0.157 \\
\hline Health care providers' recommendation & 0.311 & 0.125 & 0.498 \\
\hline Mean child age & 0.014 & 0.001 & 0.027 \\
\hline
\end{tabular}

Only variables with $P<0.25$ in statistical comparison between users and non-users were entered into the analysis. 
Iranian people (41). Accessibility and the relatively low cost of medicinal herbs are among the other reasons for their use (42).

This study showed a slight but statistically significant positive association between the child's age and use of CAM. Previous studies also showed a higher prevalence of CAM use in adult populations than paediatric populations (43-45). Also, according to a study by Ottolini et al., older children were treated with CAM more than younger ones (22). This lower frequency of CAM use in children, especially the younger ones, may be due to parental considerations about the potential adverse events of herbs on smaller children.

Ourstudyhad somelimitations. Itwas notapopulation- based survey and our results are not generalizable to the entire population. Moreover the sample size was not large enough to be really representative of the population variations. Lack of a validated questionnaire is a common methodological problem in the most surveys like ours (9). Another consideration in interpreting our results is that supplements (vitamins, probiotics and fish oil) were not considered as CAM in our study.

As a conclusion, this study demonstrated a high prevalence of CAM use, particularly herbal remedies, in paediatric patients with hepatogastrointestinal diseases, which was independently and significantly associated with previous positive experience, healthcare providers' recommendation and older age of the child.

\section{Acknowledgements}

The authors would like to thank the Research Centre for Traditional Medicine and History of Medicine and the Vice Chancellery of Technology and Research of Shiraz University, all of the study participants for their participation, and Dr Nasrin Shokrpour at the University's Research Consultation Centre for editing the final manuscript.

Funding: This study was supported by Shiraz University of Medical Sciences (grant number: 92-6709) and Fasa University of Medical Sciences (grant number: 96078).

\section{Utilisation des médicaments complémentaires et alternatifs chez les patients pédiatriques atteints de maladies hépato-gastro-intestinales \\ Résumé}

Contexte : L'utilisation des médicaments complémentaires et alternatifs (MCA) est de plus en plus populaire dans les pays du Moyen-Orient. Ils sont souvent employés pour traiter les problèmes médicaux pédiatriques tels que les troubles gastro-intestinaux chroniques et les retards staturo-pondéraux. Elles sont aussi couramment utilisées chez les patients atteints de maladies hépatiques chroniques telles que la cirrhose et chez les patients ayant reçu une greffe de foie.

Objectifs : La présente étude avait pour objectif d'évaluer la prévalence de l'utilisation des médicaments complémentaires et alternatifs ainsi que les types de médicaments et les facteurs associés chez les enfants souffrants de maladies hépatogastro-intestinales à Chiraz, en République islamique d'Iran.

Méthodes : Dans une étude transversale réalisée entre septembre 2013 et janvier 2014, 238 parents d'enfants consultant dans une clinique d'hépatologie et de gastro-entérologie pédiatrique à l'Université des Sciences médicales de Chiraz ont reçu un questionnaire auto-administré couvrant les facteurs associés à l'utilisation des médicaments complémentaires et alternatifs ; 210 questionnaires ont été remplis et renvoyés.

Résultats : Des médicaments complémentaires et alternatifs étaient utilisés pour le traitement de 103 patients (49\%); $74(71,8 \%)$ d'entre eux utilisaient des remèdes à base de plantes. Ces médicaments étaient beaucoup plus utilisés chez les enfants plus âgés. Les répondants ayant eu des expériences précédentes positives avec des médicaments complémentaires et alternatifs (62,1\% d'utilisateurs, 40,2 \% de non-utilisateurs) et ceux à qui des prestataires de soins de santé avaient recommandé ces médicaments (24,3\% d'utilisateurs, 6,6\% de non-utilisateurs) étaient beaucoup plus susceptibles d'utiliser les médicaments complémentaires et alternatifs.

Conclusions: La présente étude a montré la forte prévalence de l'utilisation des médicaments complémentaires et alternatifs (en particulier les remèdes à base de plantes) chez les patients pédiatriques atteints de maladies gastrointestinales. 


\section{استخدام الطب البديل و التكميلي للأطفال المرضى بأمر اض الكبد و المعدة و الأمعاء \\ سيد حمداله مساو ات، مجتبى حيدري، محمد هاشم هاشم بور، سيد محسن دهقاني

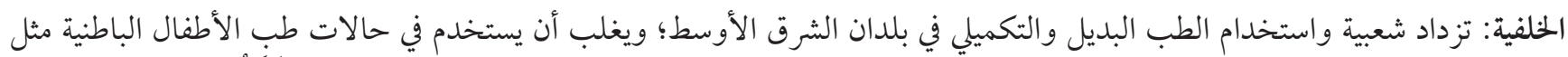

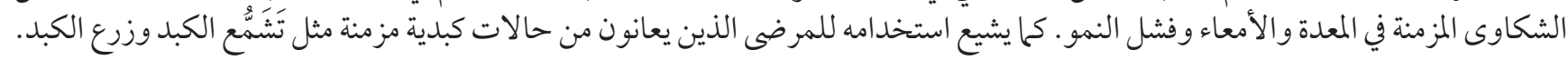

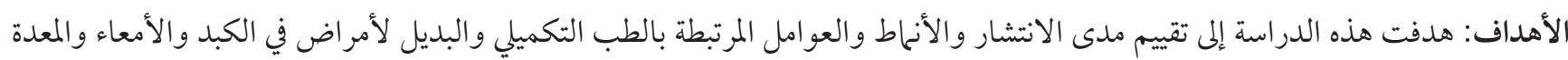
للأطفال، في شيراز في جمهورية إير ان الإسلامية.

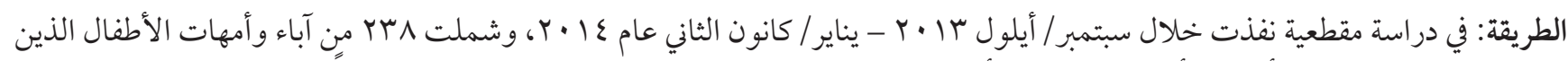

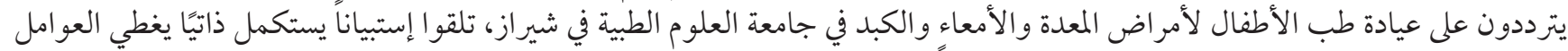

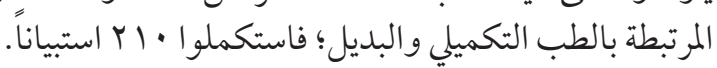

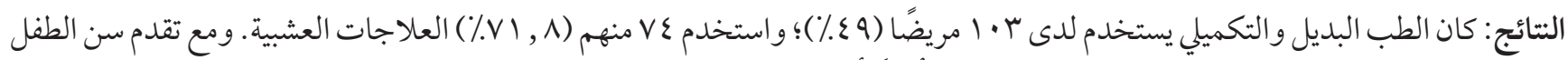

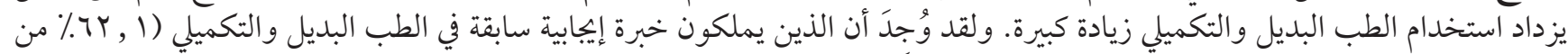

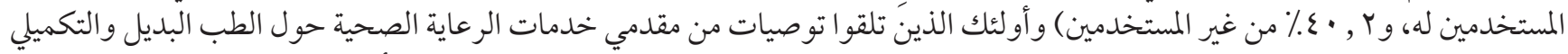

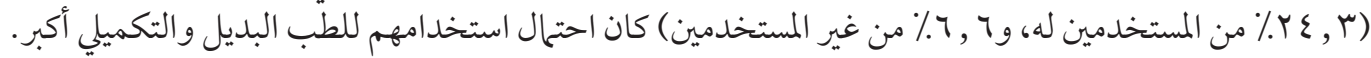

الاستتاجات: أظهرت هذه الدراسة ارتفاع معدل انتشار استخدام الطب البديل والتهاء التكميلي (ولا سيا المعالجات العشبية) للأطفال المرضى الذين يعانون من أمر اض في الكبد و المعدة والأمعاء.

\section{References}

1. Harris PE, Cooper KL, Relton C, Thomas KJ. Prevalence of complementary and alternative medicine (CAM) use by the general population: a systematic review and update. Int J Clin Pract. 2012 Oct;66(10):924-39. https://doi.org/10.1111/j.1742-1241.2012.02945.X PMID:22994327

2. Complementary, alternative, or integrative health: what's in a name? Bethesda, Maryland: National Institutes of Health, National Center for Complementary and Integrative Health; 2008 (https://nccih.nih.gov/sites/nccam.nih.gov/files/Whats_In_A_Name_0616-2016.pdf, accessed 18 March 2018).

3. Noras MR, Yousefi M, Kiani MA. Complementary and alternative medicine (CAM) use in pediatric disease: a short review. Int J Pediatrics. 2013;1(2):45-9. DOI: 10.22038/ijp.2013.2259

4. Gottschling S, Gronwald B, Schmitt S, Schmitt C, Längler A, Leidig E, et al. Use of complementary and alternative medicine in healthy children and children with chronic medical conditions in Germany. Complement Ther Med. 2013 Apr;21 Suppl 1:S61-9. https://doi.org/10.1016/j.ctim.2011.06.001 PMID:23578919

5. Wong AP, Clark AL, Garnett EA, Acree M, Cohen SA, Ferry GD, et al. Use of complementary medicine in pediatric patients with inflammatory bowel disease: results from a multicenter survey. J Pediatr Gastroenterol Nutr. 2009 Jan;48(1):55-60. https://doi. org/10.1097/MPG.obo13e318169330f PMID:19172124

6. Davis MP, Darden PM. Use of complementary and alternative medicine by children in the United States. Arch Pediatr Adolesc Med. 2003 Apr;157(4):393-6. https://doi.org/10.1001/archpedi.157.4.393 PMID:12695237

7. Adams D, Schiffgen M, Kundu A, Dagenais S, Clifford T, Baydala L, et al. Patterns of utilization of complementary and alternative medicine in 2 pediatric gastroenterology clinics. J Pediatr Gastroenterol Nutr. 2014 Sep;59(3):334-9. https://doi.org/10.1097/ MPG.0000000000000439 PMID:24854897

8. Ozturk C, Karayagiz G. Exploration of the use of complementary and alternative medicine among Turkish children. J Clin Nurs. 2008 Oct;17(19):2558-64. https://doi.org/10.1111/j.1365-2702.2008.02329.x PMID:18808623

9. Posadzki P, Watson L, Alotaibi A, Ernst E. Prevalence of complementary and alternative medicine (CAM)-use in UK paediatric patients: a systematic review of surveys. Complement Ther Med. 2013 Jun;21(3):224-31. https://doi.org/10.1016/j.ctim.2012.11.006 PMID:23642955

10. Lin YC, Lee AC, Kemper KJ, Berde CB. Use of complementary and alternative medicine in pediatric pain management service: a survey. Pain Med. 2005 Nov-Dec;6(6):452-8. https://doi.org/10.1111/j.1526-4637.2005.00071.x PMID:16336482

11. Haas L, McClain C, Varilek G. Complementary and alternative medicine and gastrointestinal diseases. Current opinion in gastroenterology. 2000;Mar;16(2):188-96. PMID:17024040

12. Hashempur MH, Ghasemi MS, Daneshfard B, Ghoreishi PS, Lari ZN, Homayouni K, et al. Efficacy of topical chamomile oil for mild and moderate carpal tunnel syndrome: A randomized double-blind placebo-controlled clinical trial. Complement Ther Clin Pract. 2017 Feb;26:61-7. https://doi.org/10.1016/j.ctcp.2016.11.010 PMID:28107852 
13. Qasemzadeh MJ, Sharifi H, Hamedanian M, Gharehbeglou M, Heydari M, Sardari M, et al. The effect of Viola odorata flower syrup on the cough of children with asthma: a double-blind, randomized controlled trial. J Evid Based Complementary Altern Med. 2015 Oct;20(4):287-91. https://doi.org/10.1177/2156587215584862 PMID:25954025

14. Pasalar M, Lankarani KB. Herbal medicines, a prominent component in complementary and alternative medicine use in gastrointestinal field. Am J Gastroenterol. 2015 Jun;110(6):935. https://doi.org/10.1038/ajg.2015.108 PMID:26052773

15. Roozbeh J, Hashempur MH, Heydari M. Use of herbal remedies among patients undergoing hemodialysis. Iran J Kidney Dis. 2013 Nov;7(6):492-5. PMID:24241097

16. Yekta Z, Zamani A, Mehdizade M, Farajzadegan Z. Pattern of complementary and alternative medicine use in urban population. J Res Health Sci. 200707 28;7(1):24-31. PMID:23343868

17. Tonekaboni SH, Jafari Naeini S, Khajeh A, Yaghini O, Ghazavi A, Abdollah Gorji F. Use of complementary and alternative medicine for epileptic children in Tehran: a cross-sectional study (2009-2011). Iran J Child Neurol. 2014 Winter;8(1):26-31. PMID:24665324

18. Asadi-Pooya AA, Emami M. Perception and use of complementary and alternative medicine among children and adults with epilepsy: the importance of the decision makers. Acta Med Iran. 2014;52(2):153-7. PMID:24659074

19. Arýkan D, Sívríkaya SK, Olgun N. Complementary alternative medicine use in children with type 1 diabetes mellitus in Erzurum, Turkey. J Clin Nurs. 2009 Aug;18(15):2136-44. https://doi.org/10.1111/j.1365-2702.2008.02464.x PMID:19077023

20. Zuzak TJ, Zuzak-Siegrist I, Simões-Wüst AP, Rist L, Staubli G. Use of complementary and alternative medicine by patients presenting to a paediatric emergency department. Eur J Pediatr. 2009 Apr;168(4):431-7. https://doi.org/10.1007/s00431-008-0765-3 PMID:18597113

21. Miller JL, Binns HJ, Brickman WJ. Complementary and alternative medicine use in children with type 1 diabetes: a pilot survey of parents. Explore (NY). 2008 Sep-Oct;4(5):311-4. https://doi.org/10.1016/j.explore.2008.06.002 PMID:18775401

22. Ottolini MC, Hamburger EK, Loprieato JO, Coleman RH, Sachs HC, Madden R, et al. Complementary and alternative medicine use among children in the Washington, DC area. Ambul Pediatr. 2001 Mar-Apr;1(2):122-5. https://doi. org/10.1367/1539-4409(2001)001<0122:CAAMUA>2.0.CO;2 PMID:11888385

23. Vlieger AM, van de Putte EM, Hoeksma H. [The use of complementary and alternative medicine in children at a general paediatric clinic and parental reasons for use]. Ned Tijdschr Geneeskd. 2006 Mar 18;150(11):625-30. PMID:16610506

24. Hashempur MH, Heydari M, Mosavat SH, Heydari ST, Shams M. Complementary and alternative medicine use in Iranian patients with diabetes mellitus. J Integr Med. 2015 Sep;13(5):319-25. https://doi.org/10.1016/S2095-4964(15)60196-0 PMID:26343103

25. Abramson SB. Nitric oxide in inflammation and pain associated with osteoarthritis. Arthritis Res Ther. 2008;10 Suppl 2:S2. https://doi.org/10.1186/ar2463 PMID:19007427

26. Lim JU, Joo KR, Shin HP, Cha JM, Lee JI, Lim SJ. Obstructive jaundice caused by Clonorchiasis-associated duodenal papillitis: a case report. J Korean Med Sci. 2011 Jan;26(1):135-7. https://doi.org/10.3346/jkms.2011.26.1.135 PMID:21218042

27. Hafeez M. Helminth parasites of public health importance-Trematodes. J Parasit Dis. 2003;27:69-75.

28. Yazdi EG, Minaei MB, Dabaghian FH, Ardakani MEZ, Ranjbar AM, Rastegari M, et al. Efficacy of Myrtus communis L. and Descurainia sophia L. versus salicylic acid for wart treatment. Iran Red Crescent Med J. 201410 5;16(10):e16386. https://doi. org/10.5812/ircmj.16386 PMID:25558385

29. Amiri MS, Joharchi MR, Taghavizadehyazdi ME. Ethno-medicinal plants used to cure jaundice by traditional healers of Mashhad, Iran. Iran J Pharm Res. 2014 Winter;13(1):157-62. PMID:24734067

30. Boskabadi H, Maamouri G, Ebrahimi M, Ghayour-Mobarhan M, Esmaeily H, Sahebkar A, et al. Neonatal hypernatremia and dehydration in infants receiving inadequate breastfeeding. Asia Pac J Clin Nutr. 2010;19(3):301-7. PMID:20805072

31. Lee YJ, Kim NS, Kim H, Yi J-M, Oh S-M, Bang O-S, et al. Cytotoxic and anti-inflammatory constituents from the seeds of Descurainia sophia. Arch Pharm Res. 2013 May;36(5):536-41. https://doi.org/10.1007/s12272-013-0066-x PMID:23435946

32. Nimrouzi M, Sadeghpour O, Imanieh MH, Shams Ardekani M, Salehi A, Minaei MB, et al. Flixweed vs Polyethylene Glycol in the Treatment of Childhood Functional Constipation: A Randomized Clinical Trial. Iran J Pediatr. 2015 Apr;25(2):e425 PMID:26196006

33. Esmaeili D, Mobarez AM, Tohidpour A. Anti-helicobacter pylori activities of shoya powder and essential oils of thymus vulgaris and eucalyptus globulus. Open Microbiol J. 2012;6(1):65-9. https://doi.org/10.2174/1874285801206010065 PMID:22927892

34. Nikolić M, Glamočlija J, Ferreira IC, Calhelha RC, Fernandes Â, Marković T, et al. Chemical composition, antimicrobial, antioxidant and antitumor activity of Thymus serpyllum L., Thymus algeriensis Boiss. and Reut and Thymus vulgaris L. essential oils. Ind Crops Prod. 2014;52:183-90. https://doi.org/10.1016/j.indcrop.2013.10.006

35. Ramezany F, Kiyani N, Khademizadeh M. Persian manna in the past and the present: an overview. Am J Pharmacol Sci. 2013;1(3):35-7. https://doi.org/10.12691/ajps-1-3-1

36. Farhat AS, Mohammadzadeh A, Amir M, Ramezani M. Effect of Cotoneaster tricolor pojark manna on serum bilirubin levels in neonates. Int J Pharmacol. 2006;2(4):455-8. https://doi.org/10.3923/ijp.2006.455.458

37. Azadbakht M, Pishva N, Mohammadi Samani S, Alinejad F. The effect of purgative manna on the infant jaundice. Iran J Pharm Sci. 2005;1(2):95-100. 
38. Ghotbi F, Nahidi S, Zangi M. Surveying the effect of Cotoneaster spp. (shir khesht) on neonatal jaundice. Res Med. 2006;30(4):353-61.

39. Dalfardi B, Heydari M, Golzari SE, Mahmoudi Nezhad GS, Hashempur MH. Al-Baghdadi's description of venous blood circulation. Int J Cardiol. 2014 Jun 1;174(1):209-10. https://doi.org/10.1016/j.ijcard.2014.03.199 PMID:24746501

40. Mosavat SH, Ghahramani L, Haghighi ER, Chaijan MR, Hashempur MH, Heydari M. Anorectal Diseases in Avicenna's "Canon of Medicine". Acta Med Hist Adriat. 2015;13 Suppl 2:103-14. PMID:26959635

41. Heyadri M, Hashempur MH, Ayati MH, Quintern D, Nimrouzi M, Heyadri M. The use of Chinese herbal drugs in Islamic medicine. J Integr Med. 2015 Nov;13(6):363-7. https://doi.org/10.1016/S2095-4964(15)60205-9 PMID:26559361

42. WHO traditional medicine strategy 2002-2005. Geneva: World Health Organization; 2002 (WHO/EDM/TRM/2002.1; http:// www.wpro.who.int/health_technology/book_who_traditional_medicine_strategy_2002_2005.pdf, accessed 18 March 2018).

43. Ernst E. Prevalence of complementary/alternative medicine for children: a systematic review. Eur J Pediatr. 1999 Jan;158(1):7-11. https://doi.org/10.1007/s004310051000 PMID:9950300

44. Barnes PM, Powell-Griner E, McFann K, Nahin RL, editors. Complementary and alternative medicine use among adults: United States, 2002. Bethesda, Maryland: Centers for Disease Control and Prevention; 2004 (Advance Data No. 343).

45. Wheaton AG, Blanck HM, Gizlice Z, Reyes M. Medicinal herb use in a population-based survey of adults: prevalence and frequency of use, reasons for use, and use among their children. Annals of epidemiology. 2005;15(9):678-85. 